\title{
The Interaction of Rifampicin in Association with Other Antimicrobial Drugs on Mycobacterium Fortuitum in vitro
}

\author{
Sang Jae Kim, Ok Ja Suh, Gill Han Bai, Byung Won Jin, \\ and Sung Chin Kim
}

Korean Institute of Tuberculosis, Korean National Tuberculosis Association

$=$ 국문초록 $=$

\begin{abstract}
Mycobacterium Fortuitum 에 대한 rifampicin 과 기타 항균제와의 상호작용에 관한 연구
\end{abstract}

대한결핵협회 결핵연구원

김상재·서옥자・배길한 · 진병원 · 김성진

\begin{abstract}
비결핵성 항산균증예가 점증하고 있는데다 이들의 치료도 매우 어려운 경우가 많아 크게 관심을끌고 있다. 기존 항결핵제를 이용한 치료의 어려움은 주로 대 부분의 비정형 항산균이 그러한 약제에 대해 높은 내성을 나타내고 있기 때문이다. 그러나 강력한 병합요법으로 성공적인 치료를 한 경우도 가끔 볼 수 있는데, 이는 아마도 약제간의 상승적 항균작용이 있기 때문이 아닌가 생각되어 $M$. fortuitum 에 대한 rifampicin 과 기타 항균제와의 상호작용을 관찰하였다. 그 결과 rifampicin 과 ethambutol 또는 prothionamide사이에는 강한 상승작용이 있어서, 각 약제 단독으로 약 $56-88 \%$ 의 생균수 감소를 일으킬 수 있는 농도로 서로 섞었을 때, 단독으로 처리했을 때 살아남은 균을 $99.3 \%$ 이상 더 감 소시킬 수 있었다. Rifampicin 보다 ethambutol 의 농도가 증가함에 따라 상승효과가 크 게 증가하였다.

Rifampicin 과 amikacin 과의 상승작용은 크지 않았지 만 후자의 항생제 는 $M$. fortuitum 에 대해 강 한 항균력을 가지고 있었다. Rifampicin 과 tetracycline 사이에는 다소의 상승효과가 관찰되었지 만 시험된 다른 약제들에 비하면 매우 미약하여 균에 대해 독립적으로 작용한다고 사료된다. $M$. fortsitum 은 prothionamide 와 tetracycline 에 대해서도 비교적 높은 농도이지만 감수성을 나타내고 있덨다.
\end{abstract}

\section{Introduction}

The rising incidence of atypical mycobacterioses and the problems associated with their treatment attracted considerable attention in recent years $(1,2)$. The various successes of treatment of atypical mycobacterial infection with proper combination of antituberculous drugs have been reported in many papers although almost all of pathogenic atypical * 본 연구는 1983년도 대한결핵협회 임상연구비에 의 해 이루어졌음. mycobacteria are resistant to the most of antitu-berculous drugs $(1,2,3)$. This might suggest that the treatment of patients with atypical mycobacterioses need not necessarily depend upon the results of drug sensitivity test. Occasional favorable response to combined chemotherapy might be resulted from the synergistic effect of drugs used.

In this study, we have investigated in vitro interaction of rifampicin in association with other antimicrobial drugs on the growth of Mycobacterium fortuitum. 


\section{Materials and Methods}

Strain and inoculum preparation:

M. fortuitum KTM 29 was used in this study and the culture was maintained on LöwensteinJensen (L-J) medium. In order to obtain enough bacillary mass, successive subculture was made in Sauton's liquid medium in several genrations.

Bacillary mass was homogenized in a screw-capped bottle $(1 / 2$ ounce) with 6 to 8 glass beads $(3 \mathrm{~mm}$ diameter) and $0.5 \mathrm{ml}$ of distilled water on Voltex mixer, and dispersed bacilli were suspended in sterile saline. After settling down the large clumps, the supernatant was transferred into a sterile cuvette and its turbidity was adjusted to have 88 to $90 \%$ transmittance at $650 \mathrm{~nm}$. Bacterial suspension was then diluted to $10^{-4}, 1 / 2 \times 10^{-4}$, and $1 / 4 \times 10^{-4}$. Then $0.15 \mathrm{ml}$ of each dilution inoculated on drugfree media. Media containing the various concentrations of drugs in combination or alone were inoculated with approximately $10^{2} 10^{3}, 10^{4}, 10^{5}$, and $10^{6}$ viable cells. The medium used for this study was Kirchner semiliquid medium supplemented with 10 $\%$ horse serum.

Drugs and their concentrations tested:

In preliminary sensitivity tests with amikacin (AKC), cephalosporin, cycloserine, ethambutol (EMB), isoniazid, p-aminosalicylic acid, prothionamide $(\mathrm{PTH})$, rifampicin (RFP), and tetracycline (TC), considerable sensitivity of a test strain was noticed only to amikacin, prothionamide, and tetracycline.

In order to determine drug concentrations which inhibit 20 to $90 \%$ of viable organisms, the proportional sensitivity tests with diluted inocula were performed using narrowly expanded ranges of drug concentrations. For the combination of rifampicin with amikacin, ethambutol, prothionamide and tetracycline, the following concentrations were prepared: rifampicin: $1.78,3.56,7.13 \mathrm{nM}$ (equivalent to $1.5,3,6 \mathrm{mcg} / \mathrm{ml})$; amikacin: $0.26,0.39$, $0.52 \mathrm{nM}$ (equivalent to $0.2,0.3,0.4 \mathrm{mcg} / \mathrm{ml}$ ); ethambutol: $9.79,19.57,39.14 \mathrm{nM}$ (equivalent to $2,4,8 \mathrm{mcg} / \mathrm{ml}$ ) ; prothionamide: $4.44,6.66,8$. $88 \mathrm{nM}$ (equivalent to $1.4,2.4,3.4 \mathrm{mcg} / \mathrm{ml}$ ).

The proportional sensitivity of $M$. fortuitum was tested to those drug concentrations in combination or alone. Colony count of inoculated media was performed after 9 day incubation at $37^{\circ} \mathrm{C}$.

\section{Results}

Of the various drugs tested, $M$. fortuitum KTM 29 was highly sensitive to amikacin and relatively sensitive to prothionamide and tetracycline, showing total growth inhibition of approximately 4.3 $\times 10^{4}$ viable cells inoculated, at $1.3 \mathrm{nM}$ of amikacin, $44.36 \mathrm{nM}$ of prothionamide, and $10.4 \mathrm{nM}$ of tetracycline.

Striking synergism was observed in combination of rifampicin and ethambutol or prothionamide as seen in figure 1 and 2. The $3.56 \mathrm{nM}$ of rifampicin and $19.57 \mathrm{nM}$ of ethambutol reduced viable units from $\log 6.377$ to 6.021 or 5.592 , but the association of both reduced up to $\log 2.586$, indicating more than $99.9 \%$ reduction of viable cells which were survived by the treatment of either one drug alone. Increasing concentration of ethambutol in combination with rifampicin reduced much more viable cells than increasing concentrations of rifampicin. The combinations of $3.56 \mathrm{nM}$ of rifampicin with 9.79 or with $19.57 \mathrm{nM}$ of ethambutol reduced viable cells from $\log 6.377$ to 4.909 or 2.586 respectively.

The $3.56 \mathrm{nM}$ of rifampicin and $6.66 \mathrm{nM}$ of prothionamide lowered viable units from $\log 6.377$ to 6.021 and 5.458 respectively, but it was reduced to $\log 3.301$ when combined both, showing more than $99.3 \%$ reduction of viable cells which were survived by the treatment of either one drug alone. Viable units could be reduced up to $\log 3.067$ or to 2.971 with the combinations of 6. $66 \mathrm{nM}$ of prothionamide and $7.13 \mathrm{nM}$ of rifampicin or of $8.88 \mathrm{nM}$ of prothionamide and $3.56 \mathrm{nM}$ of rifampicin as seen in figure 2. Synergistic effect between ethambutol and rifampicin was 


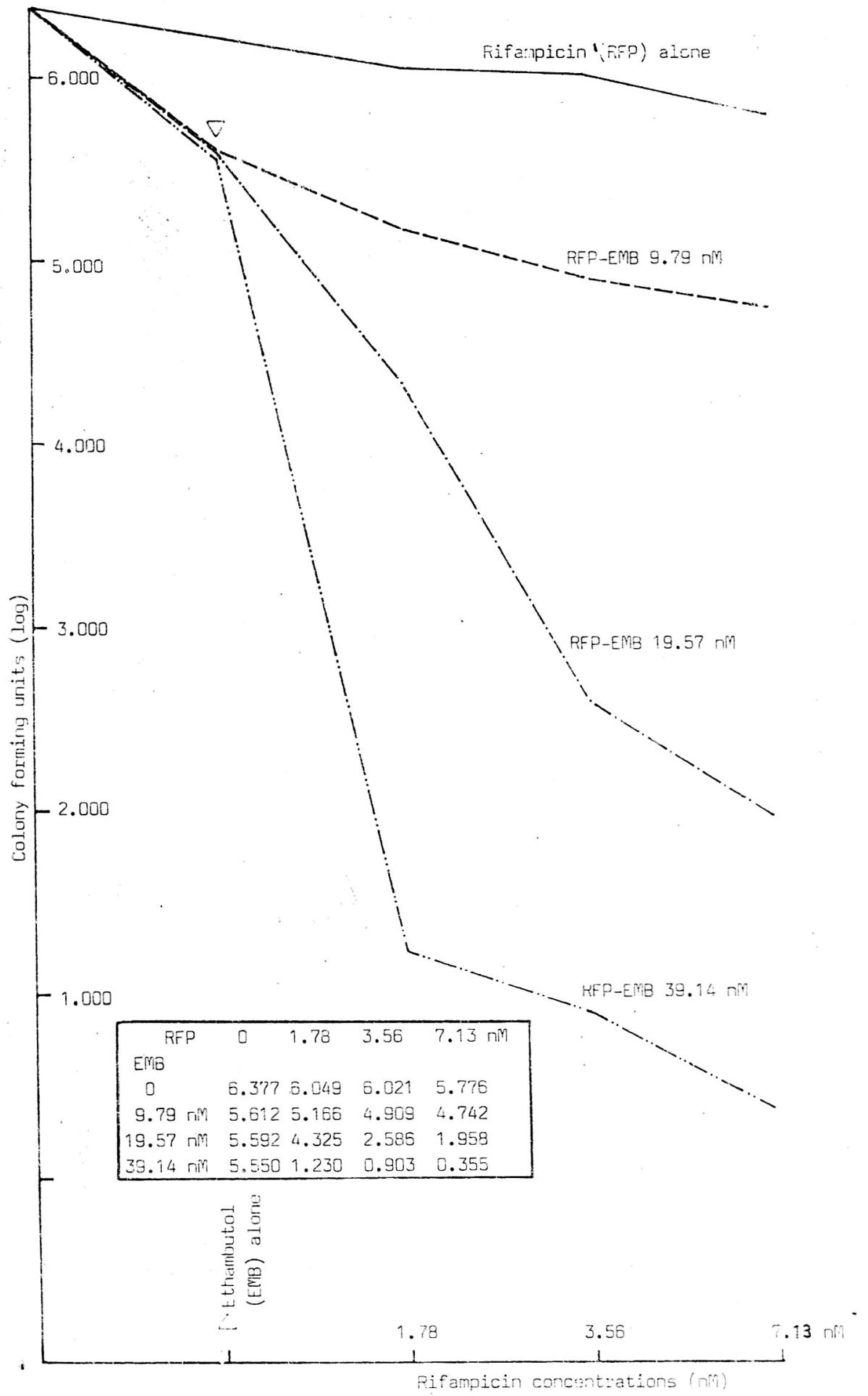

Fig. 1. Interaction of rifampicin in association with ethambutol on Mycobacterium fortuttum. Numbers in a square represent log number of colony forming cells per ml of noculur. 
greater than that of prothionamide-rifampicin combinations. Ethambutol (19.57 nM)-rifampicin (3.56 $\mathrm{nM}$ ) combination decreased viable units from $\log _{1} 6.377$ to 2.586 and prothionamide $(6.66 \mathrm{nM})$ rifampicin (3.56 $\mathrm{nM})$, to $\log 3.301$; however, combination of all three drugs reduced viable units up to 0.204 indicating further potentiation by this triple regimen.

Three concentrations of amikacin decreased viable units from $\log 6.182$ to $5.553,4.815$ and 3.467 respectively, and in association with 3.56 $\mathrm{nM}$ of rifampicin, they reduced to $\log 4.602$ or less

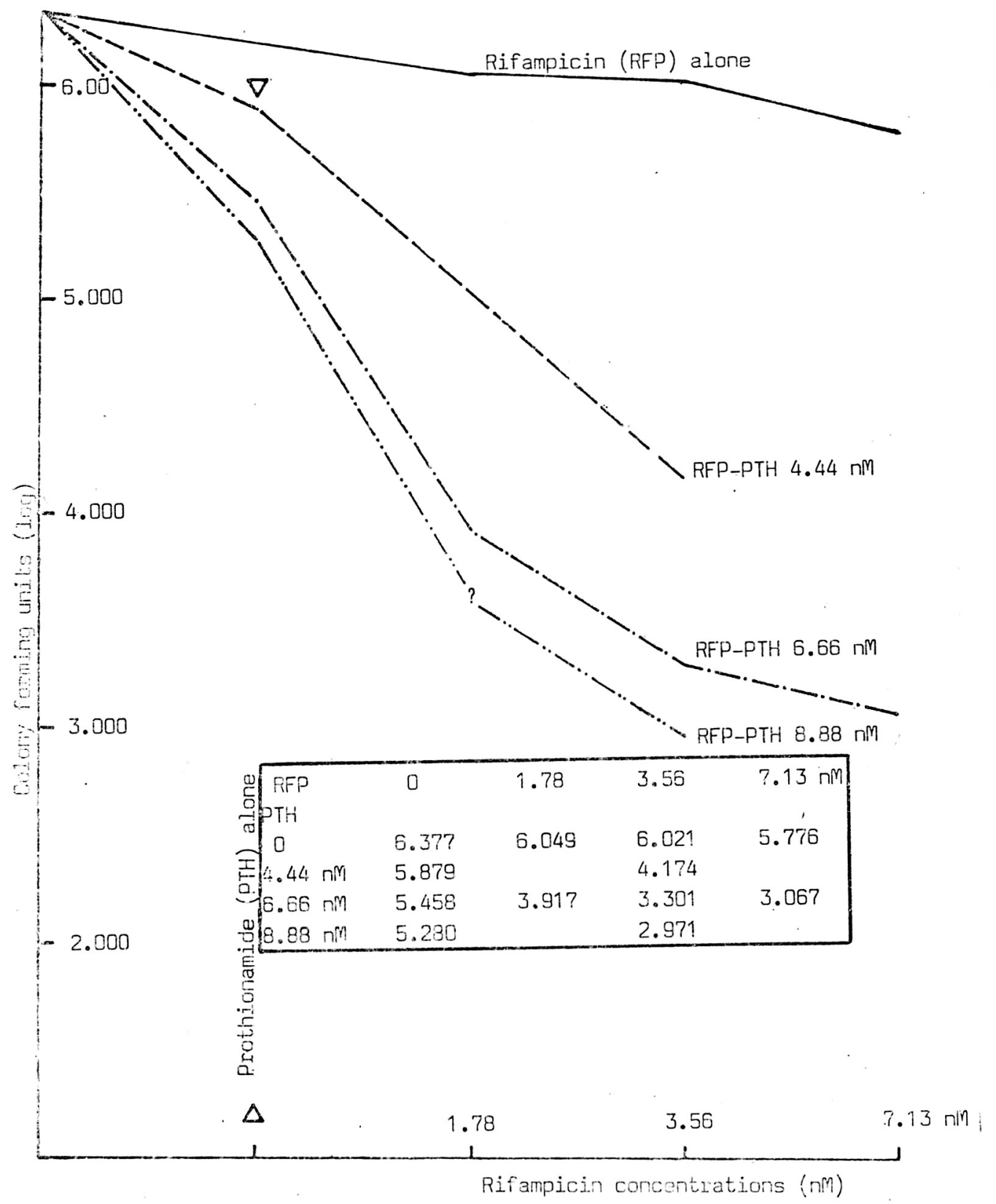

Fig. 2. Interaction of rifampicin in association with prothionamide on Mycobacterium fortuitum Numbers in a square represent log number of colony forming cells per $\mathrm{ml}$ of inoculum. 
than 2.000 as seen in figure 3. The association of $1.78 \mathrm{nM}$ of rifampicin with $0.39 \mathrm{nM}$ of amikacin reduced viable units from $\log 5.930$ or 4.815 which were survived by the? treatment"of either one drug alone, to $\log 2.727$, indicating more than $99.2 \%$ reduction.

Three concentrations $(2.91,4.99$ and $7.07 \mathrm{nM})$ of tetracycline reduced viable cells from $\log 6.182$ to $5.926,5.858$, and 5.745 respectively. The combination of $1.78 \mathrm{nM}$ of rifampicin with $4.99 \mathrm{nM}$ of tetracycline decreased viable units to $\log \mathbf{5 . 4 3 5}$ and $3.56 \mathrm{nM}$ of rifampicin with each of three concentrations of tetracycline reduced to log 5.514, 5.125, and 4.924. The combination of $7.13 \mathrm{nM}$ of

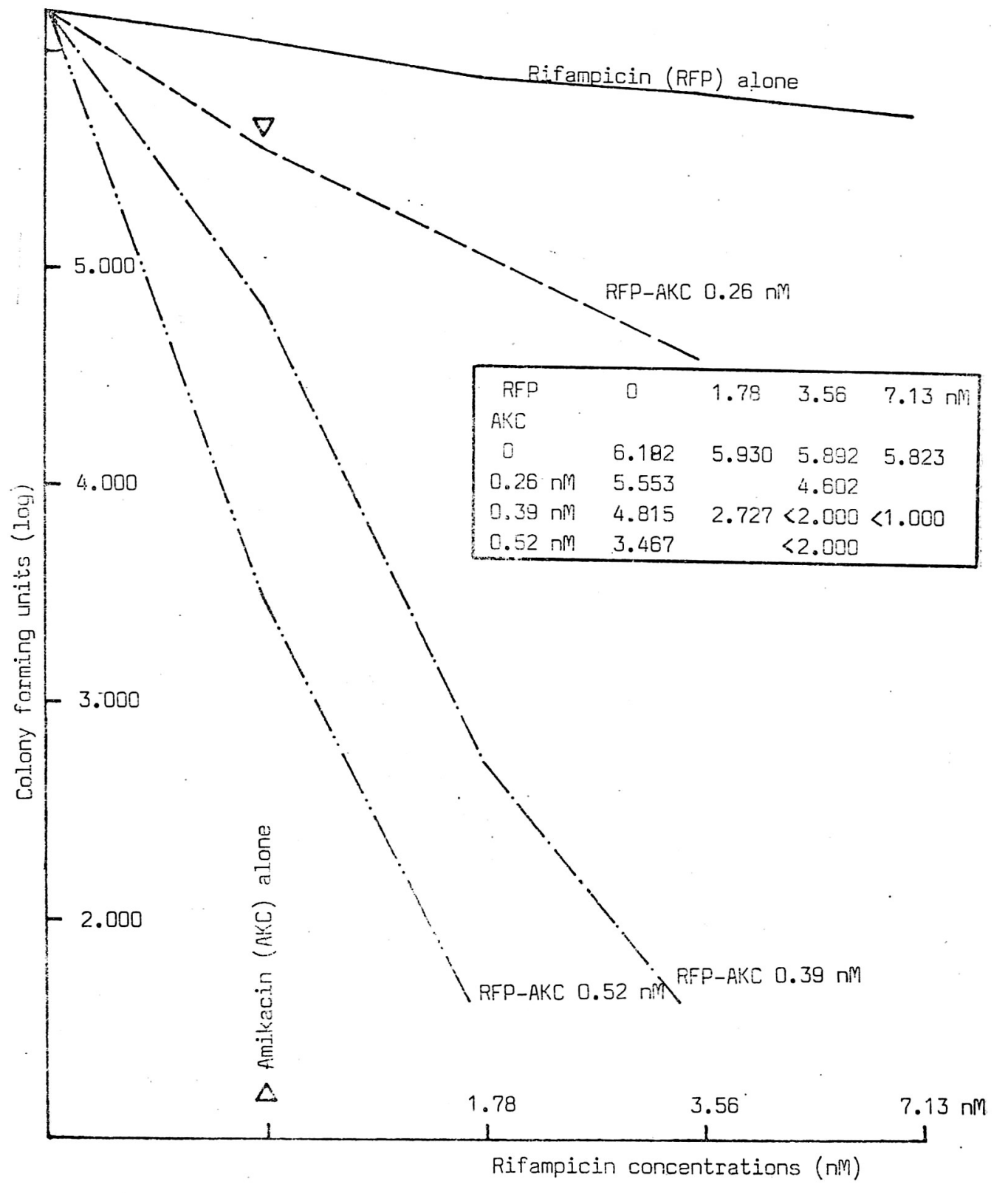

Fig. 3. Interaction of rifampicin in association with amikacin on Mycobacterium fortuitum. Numbers in a square represent log number of colony forming cells per $\mathrm{ml}$ of inoculum. 
rifampicin with $4.99 \mathrm{nM}$ of tetracycline reduced up to $\log 4.951$ from 6.182 viable cells, but no total inhibition was observed. Highest reduction was noticed in the combination of $3.56 \mathrm{nM}$ of rifampicin with $7.07 \mathrm{nM}$ of tetracycline, showing less than $90 \%$ reduction of viable cells survived by treating with either one drug alone.

\section{Discussion}

The combined chemotherapy of antituberculous drugs is usual practice for the treatment of tuberculosis and it is aimed to rapid disappearance of the largest possible number of bacilli, probably

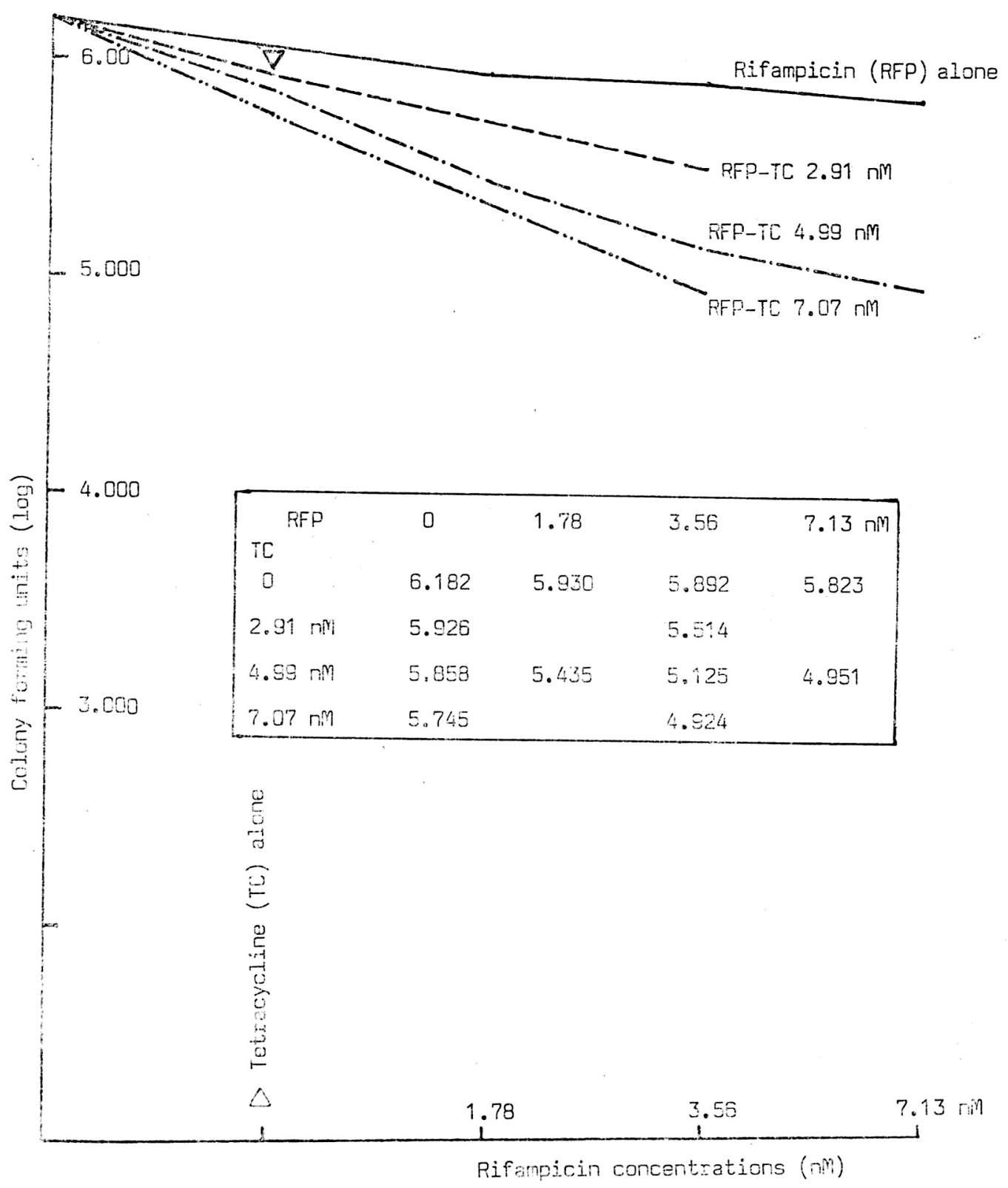

Fig. 4. Interaction of rifampicin in association with tetracycline on Mycobacterium fortuitum. Numbers in a square represent log number of colony forming cells per $\mathrm{ml}$ of inoculum. 
due to multiple metabolic lesions caused, and to prevent the selective growth of resistant bacilli $(4,5)$. Additional advantage in some combination of drugs is the sparing effect on concomittantly administered drug by competing with each other for inactivation in the body (6).

However, chemotherapeutic response of patients with nontuberculous mycobacterioses was variable and often produced poor results, presumably due to high resistance to most of antituberculous drugs $(1,2,3)$. But some favorable response had been occasionally documented when patients were treated with proper combined chemotherapy of those including rifampicin, ethambutol, prothionamide, pyrazinamide, cycloserine or kanamycin. Favorable response could be expected if those regimens have synergistic interaction between drugs included. Strong synergism between rifampicin and ethambutol had been observed in tuberculosis $(7,8)$ and kanamycin and ethambutol was very effective combination in murine atypical mycobacteriosis (9).

In this study we oberved some interaction aspects of rifampicin with other antimicrobial drugs on $M$. fortuitum in vitro. To show clearcut interaction between drugs in the combinations, we used drug concentrations, which inhibited growth of 44 to 95\% of cultivable cells. The results showed that rifampicin plus ethambutol or rifampicin plus prothionamide revealed striking synergism but much less prominent in the combination of rifampicin with amikacin even if amikacin was the most effective antibiotic against $M$. fortuitum. The association of rifampicin and ethambutol with concentrations which showed 56 to $84 \%$ growth inhibition suppressed growth of $99.9 \%$ of viable cells which were survived by the treatment of either one drug alone The higher concentration of ethambutol in combinations, the greater synegism was observed. However, increased synergism with increasing concentrations of rifampicin was obtained when combined with $19.57 \mathrm{nM}$ of ethambutol. Similar synergistic effect was obtained with the combination of $84 \%$. growth inhibitory concentr- ation of rifampicin $(1.78 \mathrm{nM})$ with $88 \%$ growth. inhibitory concentration of prothinamide $(6.66 \mathrm{nM})$, but it was less prominent than that of rifampicinethambutol combination. Tetracycline did not show apparent synergism with rifampicin but some additive effect could be obtained. The combination of rifampicin and tetracycline, which inhibited growth of approximately $50 \%$ of viable organisms, reduced 82 to $83 \%$ of viable cell units survived by the treatment of either one drug alone.

\section{Summary}

Selection of antimicrobial drugs effective on $M$. fortuitum and investigation on the interaction aspects of rifampicin with other antimicrobial drugs have been carried out using the drug concentrations which inhibited growth of 44 to $95 \%$ of cultivable cells. Total growth inhibition of approximately $4.3 \times 10^{4}$ viable bacilli inoculated was. obtained with $1.3 \mathrm{nM}$ of amikacin, $44.36 \mathrm{nM}$ of prothionamide, and $10.4 \mathrm{nM}$ of tetracycline. The association of $56 \%$ growth inhibitory concentration of rifampicin with $84 \%$ growth inhibitory concentration of ethambutol caused more than $99.9 \%$ reduction of viable cells which were survived by the treatment of either one drug alone. The similar synergistic effect was observed in the combination of rifampicin with prothionamide, but not much prominent with amikacin. Tetracycline seemed to act independently although some additive effect was clearly demonstrated.

\section{REFERENCES}

1) Wolinsky, E.: Nontuberculous mycobacteria and associated diseases. Am Rev Resp Dis; 119:107, 1979.

2) Davidson, P.T.: Treatment and Iong term follow-up of patients with atypical mycobacterial infections. Bull IUAT, 51:257, 1976.

3) Davidson, P.T.: The management of disease with atypical mycobacteria, Clin Notes Resp Dis., 18:3, 1980. 
4) Toman, K.: Tuberculosis. World Hlth Organization, pp 75-80, 1979.

5) Stead, W.W. and Bates, J.: Tuberculosis. In Harrison's princinples of internal medicine, by G.W. Thorn, R.D. Adams, E. Braunwald, K.J. Isselbacher, R.G. Petersdorf. 9th ed.' McGraw-Hill, pp 908-909, 1977.

6) Long E.R.: The chemistry and chemotherapy of tuberculosis. 3rd ed. Williams and Wilkins Co., Baltimore, p 351, 1952.

7) Trnka, L. and Tousek, J.: Interaction aspects of antimycobacterial drugs in the chemotherapy of tuberculosis. I. Role. of individual antituberculous drugs in drug regimens used in the the chemotherapy of human tuberculosis. Chemotherapy, 20:165, 1974.

8) Trnka, L., Mison, P. and Staflove, S.: Interaction aspects of antimycobacterial drugs in the chemotherapy of tuberculosis. II. The role of rifampicin and other drugs in the dependent of independent action of drug associations in vitro. Chemotherapy, 20:82, 1974.

9) Sakamoto, T. and Goda, T.: Effectiveness of ethambutol on mice infected with atypical acid-fast bacilli. Kekkaku, 4:233, 1966. 